\title{
The effect of exchange rate on bilateral trade balance: new evidence from Malaysia and Thailand
}

\begin{abstract}
This paper attempts to identify the major economic factors that influence the bilateral trade balances of Malaysia and Thailand with the US and Japan. To this end, an unrestricted VAR model was estimated using quarterly frequency data from 1980: I to 1996: IV. The Johansen results indicate a stable long-run relation between trade and three macro variables: exchange rate, domestic income and foreign income. The main findings of this paper are: (i) the real effective exchange rate is an important variable in the trade balance equation and devaluation improves the trade balances of both economies in the long-run; (ii) the other important variables that determine trade balance include domestic and foreign incomes; (iii) the results indicate no J-curve effect and causal run from exchange rate to trade balance, (iv) the real effects of devaluation are distributed over a period of eight to nine quarters.
\end{abstract}

Keyword: Exchange rate; Trade balance; Devaluation; Cointegration 